Available online on 15.09.2018 at http://jddtonline.info

Journal of Drug Delivery and Therapeutics

Open Access to Pharmaceutical and Medical Research

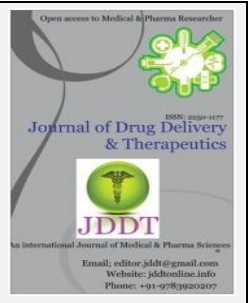

Open $\bigcirc$ Access

Review Article

\title{
AN UPDATED REVIEW ON USTUKHUDOOS PLANT
}

\author{
Aisha Siddiqui* ${ }^{1}$, Zeba Afrin ${ }^{2}$, M.A. Jafri ${ }^{3}$ \\ ${ }^{1}$ Assistant Professor, Department of Ilmul Advia, School of Unani Medical Education \& Research, Jamia Hamdard, New Delhi, \\ India \\ ${ }^{2}$ Research Associate, Central Council for Research in Unani Medicine Headquarters, Janakpuri, New Delhi, India \\ ${ }^{3}$ Professor, Department of Ilmul Advia, School of Unani Medical Education \& Research, Jamia Hamdard, New Delhi, India
}

\begin{abstract}
Lavandula stoechas Mill. commonly known as Ustukhudoos, is perhaps the most important medicinal plant in the unani system of medicine. Whole part, flowers and essential oil of the plant is used to treat a variety of diseases. A number of ailments are treated by the plant which is used either alone or in combination with other plants. It is used for the treatment of various neurological disorders like hemiplegia, facial paralysis, tremors, epilepsy, melancholia, neurasthenia. Moreover, it is used in sinusitis, liver disorders and urinary disorders etc. L. stoechas possesses antimicrobial, antidiabetic, antioxidant, antifungal, anti-inflammatory, anticonvulsant, antispasmodic, sedative, hepatoprotective activities. This article discusses and summarizes the important medicinal values of Ustukhudoos in the perspective of Unani literature as well as modern scientific research.
\end{abstract}

Keywords: Ustukhudoos, Lavandula stoechas, neurological, epilepsy

Article Info: Received 12 July, 2018; Review Completed 08 Aug 2018; Accepted 11 Aug 2018; Available online 15 Sep 2018

\section{Cite this article as:}

Siddiqui A, Afrin Z, Jafri MA, An updated review on Ustukhudoos plant, Journal of Drug Delivery and Therapeutics. 2018; 8(5):88-91 DOI: http://dx.doi.org/10.22270/jddt.v8i5.1855

*Address for Correspondence:

Aisha Siddiqui, Assistant Professor, Dept. of IImul Advia, School of Unani Medical Education \& Research, Jamia Hamdard, New Delhi. India.

\section{INTRODUCTION}

The genus Lavandula is an important member of family Lamiaceae/Labiatae. Its species are cultivated in Spain, France and Italy. It is widely distributed in the Mediterranean region. Ustukhuddus is a herb that have leaves similar to the leaves of Satar (Zataria multiflora) but thinner and longer than that. Flowers are in cluster and have smell like camphor ${ }^{1,2}$. It is stated by Dioscorides that, this plant is named stoechas as it grows on the Stoechades, a group of islands on the south coast of Gaul near Massila. It is wrongly named as 'Alfazema' in Western India. It is known as "Romero Santo" in spain which means sacred rosemerry ${ }^{3}$.

\section{Scientific Classification ${ }^{4}$}

\begin{tabular}{|l|l|}
\hline Kingdom & Plantae \\
\hline Subkingdom & Tracheobionta \\
\hline Superdivision & Spermatophyta \\
\hline Division & Magnoliophyta \\
\hline Class & Magnoliopsida \\
\hline Subclass & Asteridae \\
\hline Order & Lamiales \\
\hline Family & Lamiaceae/ Labiatae \\
\hline Genus & Lavandula \\
\hline Species & L. stoechas \\
\hline
\end{tabular}


Vernaculars ${ }^{5-10}$

\begin{tabular}{|l|l|}
\hline English & Stoechades, Arabian or French Lavander \\
\hline Hindi & Alaphajana Dharu, Ustukhuddusa \\
\hline Gujarati & Lavandara-na-phula \\
\hline Urdu & Ustukhudoos, Alfaajan \\
\hline Bengali & Tantana \\
\hline Marathi & Alphajan \\
\hline Arabic & Anisul Arwah, Mumsikul arwah \\
\hline Siryani & Sakhawis \\
\hline Persian & Shahsafram \\
\hline
\end{tabular}

\section{Habitat \& Distribution}

This herb is found throughout the Mediterranean region to Istanbul and Asia minor and in the Canaries, portugal $^{6}$. It is found in Rabi reason in forests and mountains having wet soils ${ }^{1}$. Dried plant and flowers are imported into Mumbai from Persian Gulf ${ }^{6}$. Lavandula which is cultivated in Rome and Hejaz is more potent ${ }^{1}$.

\section{Botanical Description}

Macroscopic: It is a perennial shrub up to $90 \mathrm{~cm}$, greytomentose. Leaves are linear, sessile, entire with somewhat revolute margins. Flowers are dark purple in colour, about $4 \mathrm{~mm}$ long and in dense short peduncled spikes with terminal tuft of large purple bracts. Flowers are situated in the axils of downy, heart shaped bracts. Flowering occurs in june-july. The drug sample consists of dried spikes with peduncles. The peduncles are greyish brown in colour and quadrangular. It is bitter in taste and gives a slight aromatic odour ${ }^{7}$.

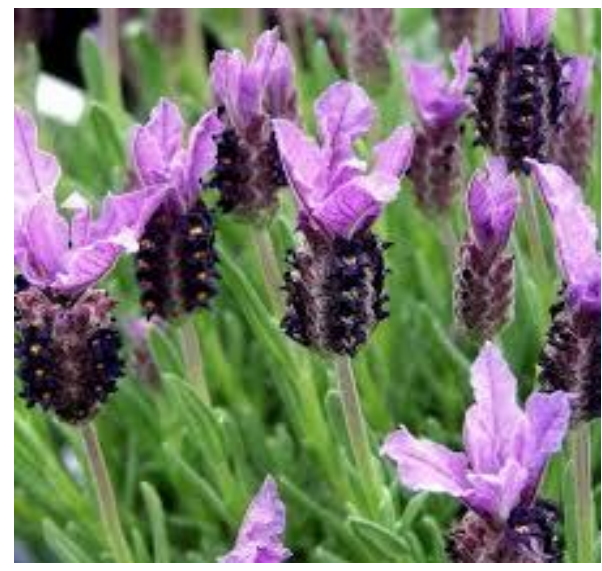

Ustukhudoos Flowers

\section{Microscopic Characteristics:}

Microscopic examination of the spikes shows that the flowers are borne in the axils of quite large, acuminate, rhomboid, leafy bracts. The bracts measure 6.5 to $8.5 \mathrm{~mm}$ in length, $6-7 \mathrm{~mm}$ in the breadth in middle and have prominent veins.

The flowers are shortly stalked. Tubular and measures 7 to $9 \mathrm{~mm}$ in length with prominent veins. It has tubular calyx, not cleft but bears at its mouth single, tongue like, ovate tooth at the back. It bears 13 prominent nerves along its length. On its surface, it bears dense tomentum of branched, stellate hairs and minute glands.

At the base, a four chambered disc with 4 seeds is present. The seeds are ovate in shape, smooth, measuring 1.4 to $1.5 \mathrm{~mm}$ in length and $0.9 \mathrm{~mm}$ in breadth in the middle.

The corolla tube is quite hairy and shows an opening 4 stamens. The anthers are 2-celled with hairs all around and brownish in colour. The pollen grains are almost rounded, smooth and 39.4 microns in diameter approximately. The style measures about $1.4 \mathrm{~mm}$ in length and whole gynoecium is about $1.8 \mathrm{~mm}$ long.

Peduncle: A cross section of the peduncle shows that it is quadrangular in shape forming 4 lobes. The surface is covered densely with hairs which are mostly tufted and stellate. Characteristic short stalked glands are present.

It shows an outer cuticle which is followed by a single layered epidermis and a few layered hypodermis in the lobes. Vascular structure consists of 4 prominent collateral vascular bundles. Vessels are confined to the 4 vascular bundles. At the centre, large zone of pith is present which consists of rounded parenchymatous cells mostly ${ }^{7}$.

\section{Part Used Medicinally}

Whole plant, flowers, Essential oil ${ }^{7}$

\section{Temperament}

Hot $1^{\circ}$ Dry $2^{\text {o }} 1,7,9,11$

Hot $2^{\circ}$ Dry $2^{\circ}{ }^{1,10}$

Hot $2^{\circ}$ Dry $3^{\text {o } 1}$

\section{Dosage}

$3 \mathrm{gm}^{7}$

7-10gm, better to use with Sikanjbeen (As mentioned by Rhazes) $)^{9,10}$

\section{Toxicity}

Harmful for people of hot and safravi temperament, increases thirst and causes nausea ${ }^{1,10,11}$.

\section{Correctives}

Kateera (Astragalus gummifer) $)^{1,7,10,11}$

Sikanjabeen ${ }^{1,11}$

\section{Substitute}

Akasbel (Cuscuta reflexa, Aftimoon) $)^{1,7,11}$

Frasiyun (Marrubium vulgare) $)^{1,11}$

\section{Compound Formulations}

Majoon Najah ${ }^{3}$

\section{Pharmacological Actions}

> Muhallil (Anti-inflammatory) $)^{1,7,10,11}$

$>$ Mulattif (Demulcent) $)^{1,10,11}$

$>$ Muqawwi (Tonic) $)^{1,10,11}$

$>$ Munaqqi (Purifier) ${ }^{1}$

$>$ Munaqqi Dimagh (Brain purifier) $)^{1,10}$

$>$ Muqawwi Aasab (Nervine tonic) ${ }^{7,9}$

$>$ Mufatteh Sudad (Deobstruent ${ }^{1,9,10,11}$

$>$ Muqawwi Dimagh (Brain tonic) ${ }^{1,11}$

> Muqawwi Qalb (Cardio tonic) ${ }^{1,10,11}$

$>$ Mufarreh $^{10}$ 
$>$ Muqawwi Meda (Stomachic) $)^{1,11}$

$>$ Mushile Balgham wa Safra wa Sauda (Purgative of phlegm, yellow bile and black bile $)^{1,10,11}$

$>$ Muqawwi Jigar (Hepatoprotective) $)^{1,11}$

$>$ Tiryaq (Antidote) $)^{10,11}$

$>$ Daafe Ufoonat (Antiseptic) $)^{9,10,12}$

$>$ Jaali (Detergent) ${ }^{10}$

$>$ Dafe Tashannuj (Antispasmodic) ${ }^{1,12}$

$>$ Anti-depressive ${ }^{12}$

$>$ Munavim $(\text { Sedative })^{12}$

$>$ Antibacterial $^{12}$

$>$ Dafe-Tashannuj (Anticonvulsant) ${ }^{12}$

\section{Therapeutic Uses}

$>$ Falij (Hemiplegia) $^{7}$

$>\quad$ Laqwa (Facial paralysis) ${ }^{7}$

$>$ Rasha (Tremor) ${ }^{1,10,11}$

> Iltihab Tajaweef-e-Anf (Sinusitis) ${ }^{12}$

$>\quad$ Nazla Muzmin (Chronic catarrh) ${ }^{1,11}$

$>$ Zof-e-Aasab (Neurasthenia) $)^{1,9}$

$>$ Malikhuliya (Melancholia) $)^{1,9}$

$>\operatorname{Sara}$ (Epilepsy) $)^{1,9,11,12}$

$>$ Rheumatic and neuralgic pains $1,9,10,11,12$

$>$ Suda (Nervous headache) ${ }^{12}$

$>$ Chest affections ${ }^{1,11}$

$>$ Amraz-e-Kabid (Liver disorders) ${ }^{11}$

> Amraz-e-Baul (Urinary disorders) ${ }^{1,10,11}$

$>\operatorname{Sadr}$ (Giddiness) ${ }^{11}$

$>$ Nisyan (Dementia) $)^{1,11}$

$>$ Bawaseer (Haemorrhoids) $^{11}$

$>$ Istisqa (Ascites) ${ }^{11}$

$>$ Junoon (Schizophrenia) ${ }^{1}$

$>$ Khadar (Numbness) ${ }^{1}$

$>$ Warme Kabid (Hepatomegaly) ${ }^{1}$

$>$ Depression $^{12}$

$>\operatorname{Sehr}(\text { Insomnia })^{12}$

\section{Phytochemical Constituents}

$>$ Organic: Carbohydrates, glycosides, phenolics, steroids, terpenes and resins.

> Inorganic: Aluminium, calcium, iron, magnesium, potassium and strontium ${ }^{7}$.

$>$ Aerial parts of the plant contain oleanolic, ursolic and vergatic acid, beta-sitosterol, alpha-amyrin and its acetate, lupeol, erythrodiol, luteolin, acacetin andvitexin.

$>\quad$ The leaves contain polyphenols, apigenin-7-O-betaD-glucoside, luteolin and its 7-O-beta-D-glucoside, and its 7-O-beta-D-glucuronide, rosmarinic acid, and 6-O-caffeoyl glucose. ${ }^{12}$

$>$ Chemical composition of Lavandula stoechas oil: apinene, camphene, oct-1-en-3-ol, p-cymene, 1,8cineole + limonene, cis-linalool oxide, fenchone, linalool, a-fenchol, a-campholenol, camphor, borneol, terpinen-4-ol, p-cymen-8-ol ${ }^{13}$.

$>$ The ethanolic extract of whole plant of L. stoechas Linn was reported to yield $\beta$-sitosterol, ursolic acid and an unidentified triterpenic acid. In the essential oil, 51 compounds have been described, the major ones being fenchone, pinocarvyl acetate, camphor, eucalyptol and myrthenol constituting $63.4 \%$ of the oil. A new acetylated glucoside of luteolin and two flavone glucosides were isolated from Lavandula stoechas $^{14}$.

\section{Pharmacological Studies}

> Antimicrobial activity: Antimicrobial effect of essential oil of Lavanudula stoechas was evaluated using Broth microdilution (MIC determine the minimum inhibitory concentration) methods. Essential oil of Lavandula stoechas showed highly inhibitory antimicrobial activity especially on gram positive bacteria and can be used instead of chemical drugs to treat bacterial infections ${ }^{15}$.

$>$ Spasmogenic and Spasmolytic activities: The crude extract of Lavandula steochas and its fractions were studies in vitro for the possible presence of spasmogenic and spasmolytic constituents. The crude extract of L. stoechas caused atropine-sensitive spasmogenic effect in guinea pig ileum. The study showed that L. stoechas exhibits both spasmogenic and spasmolytic activities, mediated through cholinergic and Calcium channel Blockade (CCB) like mechanism $^{16}$.

$>$ Antidiabetic and antioxidant activity: The study revealed that Lavandula stoechas essential oils significantly protected against the increase of blood glucose as well as the decrease of antioxidant enzyme activities induced by alloxan treatment. Subacute essential oils treatment induced a decrease of lipoperoxidation as well as an increase of antioxidant enzyme activities. These findings suggested that L. stoechas essential oils protected against diabetes and oxidative stress induced by alloxan treatment. These effects are in partly due to its potent antioxidant properties ${ }^{17}$.

$>$ Antifungal activity: Essential oils from the stems/leaves and flowers of Lavandula stoechas were tested for their antifungal activity using the paper disk diffusion method. The study revealed that essential oils tested were effective on the inactivation of Rhizoctonia solani and Fusarium oxysporum and less effective against Aspergillus flavus. Among the single compounds tested, fenchone, limonene and myrtenal appeared to be the more effective on the inhibition of $\mathrm{R}$. solani growth $^{18}$.

$>$ Anti-inflammatory activity: The antiinflammatory activity was evaluated by Carrageenan-Induced Rat Paw Edema method. The hydro-ethanolic extract of L. stoechas (5 and $10 \%$ ) inhibited the inflammation induced by carrageenan in rats in a dose dependent manner. At dose of 10 $\%$, L. stoechas produced a significant inhibition of inflammation at $74 \pm 7 \%$ compared to $69 \pm 10.3 \%$ for diclofenac at $1 \%$. The results clearly highlighted the significant anti-inflammatory effect of hydroethanolic extract of L. stoechas ${ }^{19}$.

$>$ Anticonvulsant activity: The aqueous-methanolic extract of L. stoechas flowers (LS) was studied for its possible anticonvulsant and antispasmodic 
activities. When tested in mice, LS $(600 \mathrm{mg} / \mathrm{kg})$ significantly reduced the severity and increased the latency of convulsions induced by pentylene tetrazole (PTZ). LS likewise reduced PTZ's lethality. The study showed that the plant extract of L. stoechas exhibits anticonvulsant activity ${ }^{20}$.

> Antispasmodic activity: The study was carried out on isolated rabbit jejunum preparations. Lavandula stoechas caused a dose-dependent $(0.1-1.0 \mathrm{mg} / \mathrm{ml})$ relaxation of spontaneous contractions. L. stoechas also inhibited $\mathrm{K}^{+}$-induced contractions in a similar dose range, thereby suggesting calcium channel blockade. The study revealed that the plant extract of L. stoechas exhibits antispasmodic activities ${ }^{21}$.

$>$ Sedative activity: The study was carried out in mice. Lavandula stoechas up to a dose of $600 \mathrm{mg} / \mathrm{kg}$ was found devoid of any hypnotic effect in mice, however, animals were found to be dull, calm and relaxed. The sedative effect of the plant extract was confirmed, as it prolonged the pentobarbital sleeping time in mice similar to that of diazepam ${ }^{21}$.

> Hepatoprotective and Nephroprotective activity: Hepatoprotective and nephroprotective effects of Lavandula stoechas essential oils (LSEO) were evaluated against malathion-induced oxidative stress in young male mice. LSEO treatment abolished all malathion-induced body gain loss,

\section{REFERENCES}

1. Ghani M. Khazainul Advia, Part III. Lahore: Sheikh Muhammad Basheer \& Sons; YNM. P. 1039-1041.

2. Jayaweera D. Medicinal Plants Used in Ceylon. Colombo:National Science Council of Sri Lanka; 1980. P. 2.

3. Anonymous. Standardisation of single drugs of unani medicine, part III. New Delhi: CCRUM, Ministry of H \& FW, Govt. of India; 1992. P. 20-25,79,80,81,83.

4. United States Department of Agriculture (USDA). (n.d.). Retrieved March 8, 2017, from USDA.gov: https://plants.usda.gov/core/profile?symbol=LAST9

5. Nadkarni K. The Indian Materia Medica Vol. 1. Bombay: A.K Nadkarni Publishers; 1936. P. 280, 482,483, 485, 501,842-843,,844-46,1203.

6. Khare CP. Indian Medicinal Plants: An illustrated dictionary. New Delhi: Springer-Verlag Berlin/Heidelberg, Springer science business media LLC. 2007. P. 189, 238,239,365,449,652-654.

7. Anonymous. Standardisation of single drugs of unani medicine, Part V. New Delhi: CCRUM, Ministry of H \& FW, Govt. of India; 1992. P. 1,4, 98-101.

8. Anonymous. Physicochemical standards of Unani Formulations, Part I. New Delhi: CCRUM, Dept. of AYUSH, Ministry of Health \& Family Welfare, Govt. of India; 1986. P. 202,203,213-215,228,229,232-234.

9. Sina I. Al Qanoon Fit Tibb. New Delhi: Ejaz Publishing House, Daryaganj; 1927. P. 39,40,61,212.

10. Baitar Ibn. Al Jamiul mufradat ul advia wal aghziya (Urdu translation, Part I). New Delhi: CCRUM; YNM. P. 54-56, 94-96, 232-233,339-341.

11. Hakeem MA. Bustanul Mufradat. New Delhi:Idara Kitabus Shifa; 2002. P. 60,67-68, 72,85-86.

12. Khare CP. Indian Medicinal Plants: An illustrated dictionary. New Delhi: Springer-Verlag Berlin/Heidelberg, Springer science business media LLC. 2007. P. 189, 238,239,365,449.

13. Bouzouita N, Kachouri F, Hamdi M, \& Chaabouni M, Volatile constituents and antimicrobial activity of Lavandula liver and kidney relative weight increase, hemodynamic and metabolic disorders, as well as hepatic and renal oxidative stress. The study suggested that L. stoechas essential oil exerts potential hepato- and nephroprotective effects against malathion-induced oxidative stress in mice. The beneficial effect of LSEO might be related, in part, to its antioxidant properties ${ }^{21}$.

\section{CONCLUSION}

This review enlightens that traditionally Lavandula stoechas is useful in various ailments primarily in neurological disorders such as hemiplegia, facial paralysis, melancholia, epilepsy, dementia, schizophrenia. Ustukhudoos has been proven scientifically to possess various pharmacological activities like anticonvulsant, nephroprotective, hepatoprotective, anti-spasmodic, anti fungal, antioxidant activities. As the preliminary investigations show promising results against neurological disorders, this aspect need to be thoroughly investigated so that it can be established as a standard drug. The scientific analysis of Ustukhudoos (Lavandula stoechas) proves many of the activities mentioned in Unani literature. Further investigations are needed to find out the mechanism of action, active principle and utility of Ustukhudoos in clinical practice. stoechas L. oil from Tunisia: Journal of essential oil research, 2005; 584-586.

14. Gabreili C, \& Kokkalau E, A new acetylated glucoside of Luteolin and two flavones glucosides from Lavandula stoechas: Pharmazie J, 2003; 58(6):426-7.

15. Sadani S, \& Alireza S, Antimicrobial activity of the essential oils of Lavandula stoechas flowers extracted by microwave: Journal of medicinal plants studies, 2016; 4(3):224-228.

16. Jabeen Q, Aziz N, Afzal Z \& Gilani AH, Spasmogenic and spasmolytic activities of Lavandula stoechas are mediated through Muscarinic receptors stimulation and calcium channel blockade: International Journal of Pharmacology, 2007; 3(1):61-67.

17. Sebai H, Selmi S, Tibi K, Souli AA, Gharbi N \& Sakly M, Lavender (Lavandula stoechas L.) essential oils attenuate hyperglycemia and protect against oxidative stress in alloxaninduced diabetic rats: Lipids in Health and Disease, 2013; 19.

18. Angioni A, Barra A, Coroneno V, \& Dessi S, Chemical Composition, Seasonal Variability and Antifungal Activity of Lavandula stoechas L. ssp. stoechas Essential Oils: Journal of Agricultural and Food Chemistry, 2006; 54:4364-4370.

19. Yassine E, Dalila B, Latifa EM, Smahan B, Lebtar S, Sana A, Phytochemical Screening, Anti-inflammatory Activity and Acute Toxicity of Hydro-ethanolic, Flavonoid, Tannin and Mucilage Extracts of Lavandula stoechas L. from Morocco: International Journal of Pharmacognosy and Phytochemical Research, 2016; 8(1):31-37.

20. Gilani A, Aziz N, Khan M, Shaheen F, Jabeen Q, Siddiqui B, Ethnopharmacological evaluation of the anticonvulsant, sedative and antispasmodic activities of Lavandula stoechas L: Journal of Ethnopharmacology, 2000; 71(1):161-167.

21. Miraj S, Lavandula stoechas L: A systematic review of medicinal and molecular perspectives: Der Pharmacia Lettre, 2016; 8(13):56-58. 